\title{
O filmowości literatury: korespondencje, powinowactwa, paralele (na przykładzie polskiego międzywojnia)
} Wojciech Otto

ORCID: 0000-0003-1172-0989

W roku 2019 nakładem Wydawnictwa Ec1 Łódź ukazała się książka zatytułowana Zawrót głowy. Antologia polskich wierszy filmowych, której redakcji podjął się pisarz, filmowiec i artysta sztuk wizualnych - Darek Foks. Na około 400 stronach zgromadził kilkaset wierszy polskich poetek i poetów XX i XXI wieku, wykazujących, jego zdaniem, inklinacje ze sztuką filmową. Wybór dokonany przez Foksa został podyktowany kilkoma czynnikami, wśród których na pierwszym miejscu wymienić należy przekonanie redaktora o ich filmowości, wyrażanej poprzez wątki i motywy wywodzące się z kręgu X muzy lub kojarzone z nią struktury fabularne i narracyjne. To intuicyjne skądinąd podejście pomysłodawcy tomu, dokonującego wyboru i klasyfikacji poszczególnych utworów, świadczy z jednej strony o dość swobodnym i relatywnym traktowaniu związków literatury i filmu we współczesnej kulturze, z drugiej - stanowi niezbity dowód na powszechnie panujące w świadomości odbiorców obu sztuk przekonanie o bogatych i głębokich relacjach sztuki słowa i sztuki obrazu.

Wektory tych oddziaływań skierowane są w obu kierunkach i przybierają rozmaite formy. W literaturze przedmiotu występują jako pogranicza, pokrewieństwa, powinowactwa, afiliacje i korespondencje, nie wyłączając również takich określeń, jak: „wspólnota” czy „oświetlanie się" sztuk ${ }^{1}$. Anita Has-Tokarz pisze o kilku perspektywach komparatywnych:

\footnotetext{
${ }^{1}$ Zob. René Wellek, „Literatura wobec innych sztuk”, w René Wellek i Austin Warren, Teoria literatury, przeł. Maciej Żurowski (Warszawa: Państwowe Wydawnictwo Naukowe, 1970); Pogranicza i korespondencje sztuk, red. Teresa Cieślikowska i Janusz Sławiński (Wrocław: Zakład Narodowy im. Ossolińskich, 1980); Intersemiotyczność. Literatura wobec innych sztuk (i odwrotnie), red. Stanisław Balbus, Andrzej Hejmej i Jakub Niedźwiedź (Kraków: Universitas, 2004); Oskar Walzel, „O wzajemnym oświetlaniu się sztuk”, przeł. Elżbieta Feliksiak, Przegląd Humanistyczny nr 4 (1966); Henryk Kurczab, Pogranicza sztuk i konteksty literatury pięknej (Rzeszów: Wyd. Wyższej Szkoły Pedagogicznej, 2001); Janusz Pelc, Słowo i obraz: na pograniczu literatury i sztuk plastycznych (Kraków: Towarzystwo Autorów i Wydawców Prac Naukowych Universitas, 2002); Maryla Hopfinger, „Literatura w kulturze audiowizualnej”, Pamiętnik Literacki z. 1 (1992); Jerzy Ziomek, Powinowactwa literatury. Studia i szkice (Warszawa: Państwowe Wydawnictwo Naukowe, 1980); Seweryna Wysłouch,

„O «wzajemnym oświetlaniu się sztuk» - raz jeszcze”, Polonistyka nr 8 (2002) oraz Literatura a sztuki wizualne (Warszawa: Wydawnictwo Naukowe PWN, 1991).
} 
- wzajemnej przekładalności tworów reprezentujących różne systemy komunikacyjne (sprawa adaptacji filmowych narracyjnych utworów literackich),

- obustronnych relacjach strukturalno-formalnych i „językowych”, próbach zapożyczania oraz przyswajania przez jeden system znakowy tematów, technik narracyjnych, ewentualnie środków wyrazu, stosowanych wcześniej przez drugi (tzw. literackość filmu oraz filmowość literatury),

- kompozycyjnych analogiach między tekstami przynależnymi do innorodnych porządków materiałowych (sposób konstrukcji świata przedstawionego w sztukach fabularnych),

- statusie literatury i filmu jako środkach przekazu, które zajmują określone miejsce i pełnią konkretne funkcje w systemie komunikacji społecznej (specyfika komunikacji literackiej i filmowej),

- partycypacji literatury i filmu w całości kultury, a co za tym idzie - możliwości oddziaływania na świadomość społeczną (kultura literacka i filmowa).

Zwraca przy tym uwagę na fakt, że podlegały one przez dziesięciolecia różnorodnym metamorfozom, wynikającym z emancypacji sztuki filmowej oraz burzliwych i dynamicznych przemian samej literatury².

W zależności od przyjętej metodologii zagadnienie tzw. filmowości literatury bywa ujmowane w rozmaitych kontekstach estetycznych, kulturowych i socjologicznych. Oprócz tradycji semiologicznej, od lat ugruntowanej w rodzimych badaniach literaturoznawczych, filmoznawczych i medioznawczych, coraz większą popularność zdobywają nowe, czasami nieoczywiste, ujęcia tematu, wychodzące naprzeciw przeobrażeniom kultury pod wpływem rozwoju nowoczesnych technologii oraz form i kanałów komunikacji kulturowej. Przedmiotem analizy stają się nie tylko wewnętrzne struktury poszczególnych dzieł literackich czy filmowych, ale ich medialne transpozycje, wpisujące się w historycznie ujmowane procesy remediacji ${ }^{3}$. W ramach kultury konwergencji mówi się np. o „filmowych afordancjach w literaturze"4, o nawiązaniach intertekstualnych czy przekładach intermedialnych ${ }^{5}$. Na użytek powyższych teorii powstają różnorodne typologie, zazwyczaj wyrywkowe i niepełne, a przy tym pomijające istotne determinanty społeczne i kulturowe, potęgując ich hermetyczność i fragmentaryczność.

Na tym tle przekonująco wypada propozycja Marii Zeic-Piskorskiej. Mimo kilku nieistotnych anachronizmów, wynikających z upływu czasu liczonego od daty publikacji, koncepcja ta nie traci na aktualności, uwzględnia bowiem zarówno czynniki zewnętrzne, kształtujące nowy typ odbiorcy oraz sytuację społeczno-kulturową, jak i wewnętrzną organizację dzieła, wprowadzając takie pojęcia, jak: „filmowość właściwa”, „wspólnota i homologia struktur”.

\footnotetext{
${ }^{2}$ Anita Has-Tokarz, „Między słowem a obrazem: afiliacje literatury i filmu (perspektywa komparatystyczna)”, Folia Bibliologica nr XLVIII/XLIX (2006-2007): 99-100.

${ }^{3}$ Zob. Jerzy Stachowicz, Komputery, powieści i kino nieme. Procesy remediacji w perspektywie historycznej (Warszawa: Wydawnictwa Uniwersytetu Warszawskiego, 2018).

${ }^{4}$ Anna Ślósarz, „Dwa bieguny filmowych afordancji w literaturze XXI wieku”, w Ze srebrnego ekranu na papier... Ślady sztuki filmowej w literaturze, red. Dorota Kulczycka (Zielona Góra: Oficyna Wydawnicza Uniwersytetu Zielonogórskiego, 2019), 21-38.

${ }^{5}$ Maria Jazownik, Leszek Jazownik, „Formy obecności filmu w literaturze fikcjonalnej, w Ze srebrnego ekranu na papier... Ślady sztuki filmowej w literaturze, 39-68.

${ }^{6}$ Maria Zeic-Piskorska, Próba typologii przejawów tzw. filmowości w utworach literackich, „Acta Universitatis Nicolai Copernici”, Filologia Polska XIX, z. 119, Torun 1981, 169-188.
} 


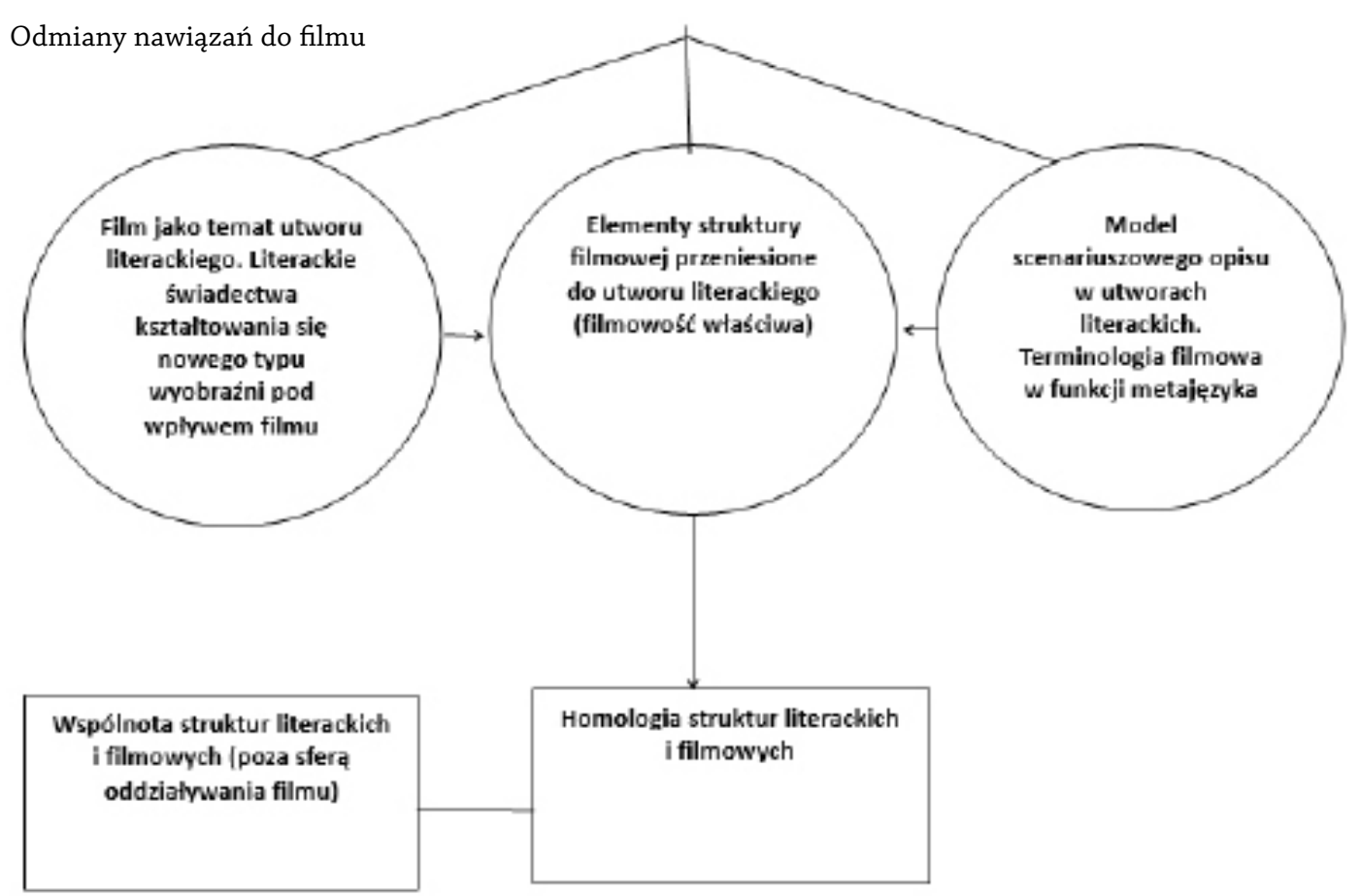

Badaczka zakłada istnienie w literaturze i w filmie punktów stycznych, których istota przejawia się przede wszystkim w zbieżności niektórych modeli wyjściowych konstruujących płaszczyzny kompozycji, narracji i postaciowania. Konsekwencją owych nawiązań jest modelowanie struktury literackiej na wzór struktury filmowej, zwane filmowością właściwą, rozumianą jako powielanie jednego czy też kilku elementów struktury filmowej, stających się dominantą kompozycyjną danego utworu literackiego. Paralelizm pewnych cząstek literackich wobec niektórych cech ontologicznych czy też kompozycyjnych filmu może powstać niezależnie, w wyniku przemian dokonujących się wyłącznie w obrębie samego procesu wewnątrzliterackiego. Takie założenie pozwala na wprowadzenie paraleli między wspólnotą sztuk a szczególnym typem homologii wynikającej ze zbieżności modelu opisu literackiego z ontologicznym charakterem opisu filmowego ${ }^{7}$.

Taka propozycja badawcza daje szerokie możliwości opisu i interpretacji zarówno poszczególnych dzieł literackich i filmowych, jak i zjawisk społeczno-kulturowych towarzyszących ich powstaniu, dystrybucji i recepcji. Związki obu sztuk, tu z naciskiem na przeobrażenia literatury pod wpływem sztuki filmowej, rozpatrywane w zawężonej do określonego miejsca i czasu perspektywie, zyskują w tym momencie wymiar zjawiska o znaczącej roli estetycznej i kulturotwórczej.

\section{Wektory oddziaływań}

W ujęciu diachronicznym, in statu nascendi bezpośrednich relacji obu sztuk, dominujące i najbardziej rozpoznane przez elity intelektualne i artystyczne tamtego czasu były zjawiska doty-

${ }^{7}$ Zeic-Piskorska, 174, 181 i 186. 
czące przeobrażeń X muzy pod wpływem literatury. Na przełomie XIX i XX stulecia kino - jako medium śmiało zmierzające na Parnas - dopiero kształtowało swój język wypowiedzi artystycznej i szukało dogodnego dla siebie miejsca w rozmaitych rejestrach kultury. Ze względu na oczywiste podobieństwa nadawczo-odbiorcze pierwszym sojusznikiem nowego medium okazał się teatr, czego pokłosiem były nieśmiałe realizacje nurtu Film d’Art (np. Zabójstwo księcia Gwizjusza na podstawie scenariusza Henriego Lavedana, 1908), ale sfilmowane spektakle teatralne $\mathrm{w}$ dłuższej perspektywie nie znalazły uznania widzów. Wówczas głos w sprawie zabrali sami twórcy filmowi, głównie z kręgu Awangardy Radzieckiej, oraz pierwsi teoretycy X muzy. W przełomowym artykule Dickens, Griffith i my Siergiej Eisenstein przekonująco dowodzi, że takie chwyty narracyjno-stylistyczne, jak: montaż równoległy, „harmonia rytmiczna” czy przenikanie obrazu i dźwięku, kojarzone powszechnie z filmowymi środkami wyrazu, kino zawdzięcza powieściom Dickensa i poematom Puszkina ${ }^{8}$. Na gruncie polskim do podobnych konstatacji dochodzi Karol Irzykowski, dostrzegając podobieństwa do dramaturgii i narracji literackiej w twórczości Davida Warka Griffitha (sekwencja montażowa w Męczennicy miłości) Jego zdaniem, „kino jako muza najmłodsza od razu stała się jakby wspólną eksperymentalnią czy śmietnikiem innych sztuk; zanim doścignie swoje koleżanki, musi przejść przez fazę prób, naśladownictw, epigoństwa" ${ }^{10}$.

Z biegiem lat, po okresie burzliwych procesów asymilacyjnych, kino wykształciło własny, autonomiczny i transparentny język wypowiedzi artystycznej, uzyskując w końcu zasłużone miano $\mathrm{X}$ muzy i zdobywając należne mu miejsce w obiegu kultury. Jak zauważa André Bazin, film, badając literaturę, naśladując jej chwyty i strategie opowiadania, przeszedł nieocenioną „lekcję kultury literackiej”, która zrodziła jego emancypacyjne aspiracje i otworzyła drogę kulturowej kariery ${ }^{11}$. Postulat ten twórczo rozwinęła Maryla Hopfinger, twierdząc, że „literatura i kultura literacka stały się dla filmu głównym i oczywistym układem odniesienia, źródłem wzorów i norm”. Jej zdaniem „to wzory kultury literackiej ułatwiły kinu zakorzenienie się w tradycji i podpowiedziały nowej praktyce komunikacyjnej program awansu artystycznego i kulturowego"12. W związku z rozwojem i ekspansją kultury audiowizualnej, na co zwracał uwagę Arnold Hauser, uznając „film za najbardziej reprezentatywny rodzaj sztuki współczesnej”13, nastąpiły wyraźne przesunięcia w relacjach między tradycyjnymi środkami przekazu, a także zmiany w wyobrażeniu i roli samej literatury. Film, stając się zdecydowanie bardziej powszechnym niż książka literacka środkiem przekazu i formą aktywności kulturalnej, po części odebrał piśmiennictwu prymarną dla niego funkcję „zwierciadła rzeczywistości” oraz rolę „opowiadacza” fabuł. Nie stał się jednak surogatem książki. Nie wyrugował w zupełności literatury ze współczesnego pejzażu semiotycznego. Obydwa systemy znakowe - literatura i film, funkcjonują w kulturze

${ }^{8}$ Siergiej Eisenstein, Wybór pism, red. Regina Dreyer, przekład zbiorowy (Warszawa: Wydawnictwa Artystyczne i Filmowe, 1959).

${ }^{9}$ Karol Irzykowski, Dziesiata Muza. Zagadnienia estetyczne kina (Warszawa: Wydawnictwa Artystyczne i Filmowe, 1977), 125.

${ }^{10}$ Irzykowski, 144.

${ }^{11}$ André Bazin, „O film nieczysty: obrona adaptacji”, w André Bazin, Film i rzeczywistość, przeł. Bolesław Michałek (Warszawa: Wydawnictwa Artystyczne i Filmowe, 1963), 85. Cyt. za: Has-Tokarz, „Między słowem a obrazem: afiliacje literatury i filmu (perspektywa komparatystyczna)", 101.

${ }^{12}$ Maryla Hopfinger, „Między reprodukcją a symulacją rzeczywistości. Problemy audiowizualności i percepcji”, w Od fotografii do rzeczywistości wirtualnej, red. Maryla Hopfinger (Warszawa: Wydawnictwo IBL, 1997), 11.

${ }^{13}$ Arnold Hauser, Społeczna historia sztuki i literatury, t. 1-2, przeł. Janina Ruszczycówna (Warszawa: Państwowy Instytut Wydawniczy, 1974), 382. 
na zasadzie uzupełniania i tworzą nowoczesne, komplementarne całości o innowacyjnych możliwościach wyrazowo-znakowych ${ }^{14}$. Wynika z tego, że mamy do czynienia z paralelnym rozwojem obu sztuk, jednak nie na zasadzie pokrewieństwa - jak referuje Jerzy Ziomek - lecz przez powinowactwa, które wskazują na wspólne korzenie literatury i filmu, pewną zastaną i naturalną symbiozę; wykazują przy tym obustronny dialog, koegzystencję kulturową, „nieraz związek z wyboru, nieraz z obowiązku, nieraz z miłości, nieraz z rozsądku" ${ }^{15}$. Janusz Plisiecki mówi w tym przypadku o swego rodzaju „wzajemnym korzystaniu z doświadczeń” ${ }^{6}$ obu sztuk, z zachowaniem ich autonomiczności, ale z możliwością oczywistych powiązań i afiliacji ${ }^{17}$.

W refleksji na temat związków filmu i literatury akcentuje się na ogół wpływ utworów literackich na dzieła filmowe, zwłaszcza w kontekście zagadnień dotyczących ekranizacji i adaptacji. Stosunkowo rzadko natomiast mówi się o zależnościach odwrotnych, mimo że egzemplifikacje tego typu relacji dostrzegano już od początków istnienia sztuki filmowej. Dla przykładu Borys Eichenbaum, przedstawiciel rosyjskiej szkoły formalnej, widział w kinie sprzymierzeńca w walce o nową literaturę, którą traktował jako „kino surowe” i szukał w niej potencjału myślenia filmowego ${ }^{18}$. Podobnie Karol Irzykowski. W utworach literackich, nawet tych powstałych w epoce przedfilmowej, dostrzega piętno „iście fotogeniczne” (Maria Malczewskiego, Ludzie bezdomni Żeromskiego, Nędznicy Hugo, Nana Zoli, Iliada Homera itd.). Stwierdza jednocześnie, że Lessing, oddzielając poezję od malarstwa, popchnął ją w kierunku kina. „Z rad Lessinga skorzystali Goethe i Schiller: znana jest iście kinowa scena z Nurka Schillerowskiego, gdzie najpierw z toni wynurza się ramię prujące wodę, potem biały kark nurka, a później ręka jego wznosi radośnie puchar królewski wydobyty z jej otchłani” ${ }^{19}$.W późniejszym okresie, mimo wyraźnych tendencji do zachowania swoistości i hermetyczności poszczególnych dziedzin sztuki, ten sposób myślenia nie stracił swoich zwolenników. André Bazin doceniał wkład kina w odnowienie warsztatu literackiego pisarz $\mathrm{y}^{20}$, Jan Białostocki natomiast odnosił tę problematykę do sztuk wizualnych w ogóle. Stwierdzał: „Literatura operuje odmiennymi od tych, którymi się posługuje sztuka, znakami. Rozgrywa się w innych wymiarach, ale na płaszczyźnie motywów, tematów, symboli może mieć i miewa związki ze sztukami wizualnymi”21. Dla przedstawionych rozważań niezwykle istotny jest również fakt, że ewolucje literatury pod wpływem filmu dostrzegali artyści, teoretycy i publicyści dwudziestolecia międzywojennego, np. Anatol Stern, Stefania Zahorska czy Jan Brzękowski ${ }^{22}$. W połączeniu ze zmianą statusu odbiorcy i uczestnika kultury oraz rozwojem popularnych obiegów literatury przekonanie to,

\footnotetext{
${ }^{14}$ Zob. Has-Tokarz, „Między słowem a obrazem: afiliacje literatury i filmu (perspektywa komparatystyczna)”, 108-109.

${ }^{15}$ Jerzy Ziomek, Powinowactwa literatury. Studia i szkice, 89.

${ }^{16}$ Janusz Plisiecki, „Przemiany w kulturze współczesnej”, w Janusz Plisiecki, Film i sztuki tradycyjne (Lublin: Wydawnictwo Uniwersytetu Marii Curie-Skłodowskiej, 1999), 21.

${ }^{17}$ Zob. również René Wellek, „Literatura wobec innych sztuk”, 175-176.

${ }^{18}$ Borys Eichenbaum, „Literatura i kino”, w Borys Eichenbaum, Szkice o prozie i poezji, przeł. Roman Zimand (Warszawa: Państwowy Instytut Wydawniczy, 1973).

${ }^{19}$ Karol Irzykowski, Dziesiąta Muza. Zagadnienia estetyczne kina, 141. Cyt. za: Joanna Kuźnicka, „Ut pictura poesis", Prace Naukowe. Pedagogika nr 8-9-10 (1999-2000-2001), 910-911.

${ }^{20}$ André Bazin, „O film nieczysty: obrona adaptacji”.

${ }^{21}$ Jan Białostocki, „Słowo i obraz”, w Słowo i obraz: materiały Sympozjum Komitetu Nauk o Sztuce PAN, red. Agnieszka Morawińska (Warszawa: Państwowe Wydawnictwo Naukowe, 1982),13.

${ }^{22}$ Anatol Stern, „U źródeł nowej estetyki”, w Anatol Stern, Poezja zbuntowana (Warszawa: Państwowy Instytut Wydawniczy, 1964), 267-515; Stefania Zahorska, „Co powieść zawdzięcza filmowi?”, Kurier Literacko-Naukowy nr 29 (1934); Jan Brzękoski, „Film a nowa poezja”, Wiadomości Literackie nr 28 (1933).
} 
skądinąd powszechnie akceptowalne, stwarzało szerokie możliwości opisu, analizy i interpretacji ewolucji sztuki słowa i sztuki ekranu tamtego okresu.

\section{Z socjologii kultury}

By móc mówić o świadomych i reprezentatywnych zapożyczeniach czy, szerzej, inspiracjach literatury sztuką filmową, należy, oprócz aspektów czysto formalnych, wziąć pod uwagę praktykę komunikacyjną między twórcą a odbiorcą oraz diagnozę społeczno-kulturową danego miejsca i czasu. Ernst H. Gombrich stwierdza, że żadnej kultury nie da się w pełni ująć w całości, ale również żadnego elementu tej kultury nie można zrozumieć w izolacji ${ }^{23}$. Na gruncie socjologii kultury oraz związków sztuki słowa i sztuki ekranu można rozumieć to jako złożone, swoiste i charakterystyczne dla danej epoki sprzężenie literatury i filmu w ramach jednej audiowizualnej formacji kulturowej ${ }^{24}$.

Przesłanki te w dużej mierze spełnia w rodzimej kulturze okres dwudziestolecia międzywojennego. Był to czas formowania się granic Polski, scalania nie tylko jej ziem, ale także całego narodu, który po wielu latach zaborów staje przed nową szansą budowania własnej państwowości, z odrębną polityką i kulturą. Jednocześnie Polska - jako nowy kraj na mapie Europy - uczestniczy w masowych przemianach cywilizacyjnych, społecznych i kulturowych, które na szeroką skalę objęły Stary Kontynent. Ruchy rewolucyjne i postęp techniczny spowodowały umasowienie kultury i zmiany w postrzeganiu człowieka jako jednostki. W sztuce pociągnęło to za sobą przewartościowanie roli artysty oraz powstanie wielu ruchów awangardowych, które zwróciły ostrze krytyki przeciw tradycji i zastanym konwencjom, szukając jednocześnie nowych form wyrazu. Rozwinęły się: kawiarnia literacka, rewia, kabaret; powstały też nowe media, przede wszystkim film i radio, które swój byt zawdzięczały zdobyczom techniki i rozwojowi nowoczesnych sposobów komunikacji.

Wszystko to stawiało sztukę słowa w odmiennym kontekście. W relacji z filmem wydawała się ona niekiedy mało atrakcyjna, kojarzona przez nowy typ odbiorcy kultury z ideami konserwatyzmu artystycznego. Reakcją na ten stan rzeczy były próby jej odrodzenia poprzez korespondencje z innymi sztukami i mediami, głównie z filmem. W pierwszych dziesięcioleciach relacja ta była oparta na zasadzie dość przypadkowych związków obu sztuk. Przejawem zainteresowania literatów filmem była z początku zarówno działalność popularyzatorska i krytyczna, jak i widoczne w konkretnych dziełach zawiązki formalne obu sztuk. Uległo jej bardzo wielu poetów i pisarzy. O aktorach i bohaterach filmowych pisali chociażby: Konstanty Ildefons Gałczyński, Roman Kołoniecki, wykorzystywali techniki filmowe: Maria Pawlikowska-Jasnorzewska, Witold Wandurski, ale z największym nasileniem owe procesy zachodziły w twórczości poetów z kręgu futurystów i Skamandra, a później również Awangardy Krakowskiej. Działalność krytyczną i teoretyczną w dziedzinie sztuki filmowej prowadzili zarówno twórcy starszego pokolenia (Karol Irzykowski), jak i młodzi literaci: Antoni Słonimski, Anatol Stern czy członkowie Awangardy Krakowskiej (Peiper, Kurek, Brzękowski).

\footnotetext{
${ }^{23}$ Ernst H. Gombrich, „W poszukiwaniu historii kultury”, przeł. Adam Dębnicki, w Pojęcia, problemy, metody wspótczesnej nauki o sztuce, red. Jan Białostocki (Warszawa: Państwowe Wydawnictwo Naukowe, 1976), 336.

${ }^{24}$ Szerzej na ten temat pisze Maryla Hopfinger w swoich pracach: Kultura wspótczesna - audiowizualność (Warszawa: Państwowy Instytut Wydawniczy, 1985); Kultura audiowizualna u progu XXI wieku (Warszawa: Wydawnictwo IBL, 1997) oraz Doświadczenia audiowizualne: o mediach w kulturze wspótczesnej (Warszawa: Sic!, 2003).
} 
Lata trzydzieste przyniosły zmiany w ramach współpracy literatów z branżą filmową. Docenienie roli literata-scenarzysty w procesie powstawania filmu oraz wspólne założenia ideologiczne przedstawicieli obu sztuk (grupa literacka „Przedmieście” i warszawski „START”) pozwoliły na zacieśnienie współpracy. Z filmem związali się jako scenarzyści - Zofia Nałkowska i Jarosław Iwaszkiewicz, a także, już z większym powodzeniem, Anatol Stern, producenci - Wacław Sieroszewski i Ferdynand Goetel (Wytwórnia „Panta-Film”), oraz autorzy słów do wielkich przedwojennych przebojów muzycznych kina - Julian Tuwim (teksty piosenek do filmu Szpieg $w$ masce Mieczysława Krawicza, 1933) i Marian Hemar (piosenki z filmów Na Sybir Henryka Szaro, 1930, Panienka z poste-restante Jana Nowiny-Przybylskiego i Michała Waszyńskiego, 1935).

Osobną kartę stanowiły inspiracje formalne technikami filmowymi. Czas bezkrytycznego zachwytu X muzą minął, a jego miejsce zajęły świadome celu zapożyczenia określonych środków wyrazowych kina. Zaczęły powstawać powieści filmowe (Jan Brzękowski: Bankructwo profesora Muellera, 1931, Psychoanalityk w podróży, 1929) oraz wiersze inspirowane technikami filmowymi (utwory Adama Ważyka, Jana Brzękowskiego). Literaci przeszli od teorii do praktyki. Filmy awangardowe realizowali: Jalu Kurek - Obliczenia rytmiczne („OR”), 1932, i Stefan Themerson (wspólnie z Franciszką Themerson) - Apteka, 1930, Europa, 1931-1932, Drobiazg melodyjny, 1934, Przygoda człowieka poczciwego, 1938.

Obecność kina w literaturze dwudziestolecia międzywojennego jest nie tylko faktem artystycznym, ale w dużej mierze może być rozpatrywana w ramach socjologii kultury polskiej tego okresu. Stefan Żółkiewski twierdzi, że tekst literacki jest dokumentem społecznym.

Dzieło może być badane jako manifestacja świadomości społecznej pisarza lub manifestacja jego sformułowanej ideologii, pośrednio zaś - jako manifestacja świadomości lub ideologii, szczególnie koherentnie wyrażonej określonych klas lub węższych grup społecznych ${ }^{25}$.

W puszce z ołowiu zostaną konserwy.

Śliska błona filmowa. Dziennik „Paramountu”.

Skok z piętnastego piętra. Nowy tank. Manewry.

Prawdziwy trup Chińczyka z mandżurskiego frontu.

(A. Słonimski, Dokument epoki)

Inspiracje filmowe literatów są więc w tym znaczeniu faktem społecznym, a treść ich dzieł obrazem epoki. Wnoszą bowiem do kultury nowe jakości, związane z przemianami narracyjnymi, fabularnymi i genologicznymi literatury. Fascynacja nowym medium przejawiała się nierzadko wprost:

- jako zachwyt nowością:

[...] zawiośniało - lato pędzi przez jesienność białośnieżnie

KINEMATOGRAF, KINEMATOGRAF, KINEMATOGRAF.

(S. Młodożeniec, XX wiek)

\footnotetext{
${ }^{25}$ Stefan Żołkiewski, Kultura. Socjologia. Semiotyka literacka. Studia (Warszawa: Państwowy Instytut Wydawniczy,
} 1979), 445 
- jako natchnienie poezji:

[...] niewysłowione, nadziemskie piękno

Kinematografu.

(J. Jankowski, Maggi)

- jako element manifestu światopoglądowego:

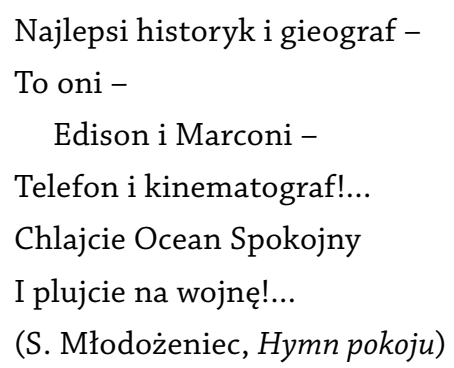

Innym był fakt społeczny mówiący o tym, że kino stanowiło dla przeciętnego Polaka tego okresu z jednej strony formę rozrywki i wypoczynku, z drugiej zaś sposób uczestnictwa w kulturze.

Pomiędzy felietonem a pójściem do kina,

W drodze między kawiarnią i znowu teatrem

(A. Słonimski, Lato $w$ mieście)

Ach kioski, szyldy, kupcy, listonosze,

Skwery, cykliści, kino-przedstawienia!

(K. Wierzyński, Lewa kieszeń)

Jeszcze innym zjawiskiem z kręgu szeroko rozumianej socjologii kultury był narastający krytyczny stosunek literatów do sztuki filmowej i przemian, jakie sprowokowała w ówczesnej sztuce. Moda na kino w literaturze, jako zjawisko socjokulturowe, przeszła swoistą ewolucję - od ślepej fascynacji po satyryczną krytykę ${ }^{26}$.

\section{[...] nie widzą nic}

Nie słyszą nic

Pathèe freres - to zwyczajni tani reklamiarze

(S. Młodożeniec, Kino)

Pauza pauza niosą ciasta

Nich pan zbytnio się nie szasta

Panie niech pan mnie nie gniecie

Bo jeszcze światło się świeci

Dramat tajemnice kryje

\footnotetext{
${ }^{26}$ Szerzej - Ewa i Marek Pytaszowie, „Poetycka podróż w świat kinematografu, czyli kino w poezji polskiej lat 1914-1925”,
} w Szkice z teorii filmu, red. Alicji Helman i Tadeusza Miczki (Katowice: Uniwersytet Śląski w Katowicach, 1978), 31-32. 


\author{
Czy on umrze czy ożyje \\ W loży śmieje się ko-ko-ta \\ Film kurz nerwy trochę błota. \\ (T. Czyżewski, Sensacja w kinie) \\ Czyżby już tylko czyż \\ Wzruszać nas mogły cysterny wilgoci \\ Mia May \\ I Liliana Gish? \\ (W. Wandurski, Precz z kanarkami)
}

Jestem nawet pewny, że byłbyś pierwszorzędnym artystą filmowym. Film jest rzeczą wielką. Film daje popularność nie dającą się z niczym porównać. Film wreszcie jest jedynym od wieków uniwersalnym teatrum wyobraźni, a zatem miejscem, gdzie najłatwiej ci będzie zahaczyć o ludzkość. [...] I oto spełni się twoje odwieczne pragnienie: albowiem - Lucyfer został artystą filmowym. Znamy go wszyscy. To Charlie Chaplin.

(A. Wat, Bezrobotny Lucyfer)

Kino jest chorobą dnia dzisiejszego. Nie pieniądze, nie kobiety, nie masoneria, nie parlamenty rządzą ziemią, wszędzie panuje kino.

(J. Kurek, S.O.S.)

Demoralizacja kina czyni zastraszające postępy w duszach. Kazałbym pozamykać te szkoły zła, zepsucia, zbrodni.

(J. Wiktor, Zwariowane miasto)

Inspiracje filmowe literatów w międzywojennej Polsce świadczyły nie tylko o rewolucji, jaka dokonała się na terenie sztuki, ale również, a nawet przede wszystkim była dowodem na przemiany światopoglądowe poszczególnych twórców oraz ich wizje kultury i ówczesnej cywilizacji wielkomiejskiej. W ujęciu socjokulturowym fakt ten świadczył o ważnej roli kina w owej kulturze, a także o jego randze jako sztuki, która inspirowała i fascynowała polską elitę intelektualną. Relacja film-literatura uwidoczniła ponadto inne zjawiska o randze społecznej, jakie zaszły w polskiej kulturze dwudziestolecia. Utwory zarówno poetyckie, jak i prozatorskie można traktować w tym ujęciu jako swoiste dokumenty epoki, świadczące o pewnych wyraźnie rysujących się procesach społecznych i artystycznych.

Na bazie tych rozważań warto przyjrzeć się bliżej konkretnym rozwiązaniom formalnym, świadczącym o tzw. filmowości literatury, a ujawniającym się jako modelowanie struktury literackiej na kształt struktury filmowej ${ }^{27}$ na jej płaszczyźnie fabularnej, narracyjnej i genologicznej. Należy przy tym zaznaczyć, że dotyczą one zwartej, spójnej i reprezentatywnej formacji kulturowej, ograniczonej do literatury polskiej oraz okresu międzywojennego (1918-1939).

\footnotetext{
${ }^{27}$ Termin „modelowania struktur” wprowadziła Maria Zeic-Piskorska, Próba typologii przejawów tzw. filmowości w utworach literackich, 174.
} 


\section{Relacje fabularne ${ }^{28}$}

Relacje fabularne, ze względu na ich przejrzystość występowania, przysparzają stosunkowo najmniej problemów. Jerzy Ziomek, odnosząc się do kategorii fabuły, wysnuwa koncepcję fabularnej wspólnoty sztuk, która ma charakter interdyscyplinarny i pozasystemowy, co oznacza, że tę samą fabułę można opowiedzieć językiem literatury, filmu czy teatru. Daje to szerokie możliwości współwystępowania określonych wątków i motywów w dziełach z różnorodnych dziedzin sztuki ${ }^{29}$.

W okresie międzywojnia literaci, wykazując w swych utworach inspiracje filmowe, rzadko kiedy kierowali się wykształconym i konsekwentnym programem poetyckim, korzystając z bogactwa filmowych środków wyrazu raczej okazyjnie i wybiórczo. W kręgu filmowych zainteresowań pisarzy znalazły się nie tylko konkretne dzieła X muzy czy wybrane wątki i motywy fabularne, ale i określone schematy fabuły (filmów komercyjnych i artystycznych) oraz szeroko rozumiany świat kina, funkcjonujący jako terminy filmowe w funkcji metajęzykowej.

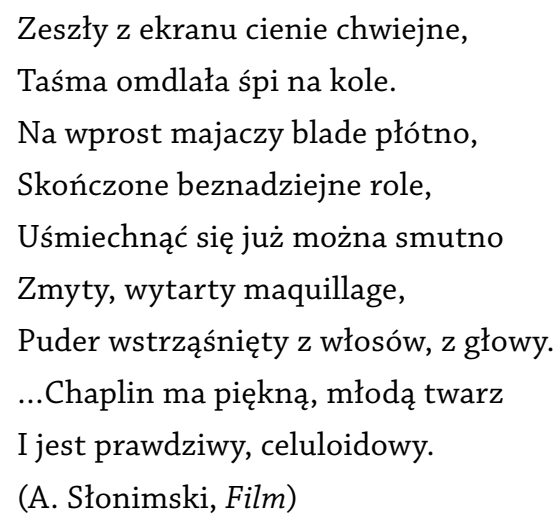

Źródła powyższych inspiracji były bardzo różne, począwszy od fascynacji kinem i jego krytyki, poprzez chęć uatrakcyjnienia literatury dla masowego odbiorcy, na odkrywaniu nowych możliwości, jakie niesie sztuka filmowa, skończywszy. W literaturze polskiej omawianego okresu świat filmu znalazł swoje odbicie w postaci opisów ówczesnych kin, obrazów z planów zdjęciowych, opisów ekipy realizatorskiej. Często wprowadzano też do fabuły przedmioty i obiekty stricte filmowe. Osobną kategorię nawiązań fabularnych stanowią rekwizyty, przedmioty i obiekty ściśle związane z X muzą. Wprowadzenie ich do świata przedstawionego literatury umożliwiało autorom stworzenie nowej rzeczywistości. Raz była nią kraina nieprawdopodobieństwa, surrealnej wyobraźni, innym razem nowoczesnej cywilizacji, jeszcze innym snu, świata cudów i magii.

Z jarmarku gwary, gdzie krzyczą papugi

W tatuowanych rękach marynarzy,

Owianych mrokiem twarzy

Na trotuarach, dachach, już płynny korowód.

Obudź się! Śpisz za długo, zwal drewniane wieko,

\footnotetext{
${ }^{28}$ Przywołując egzemplifikację literacką oraz stawiając tezy w tym artykule, posiłkuję się własną monografią - Wojciech Otto, Literatura i film w kulturze polskiej dwudziestolecia międzywojennego (Poznań: Wydawnictwo Poznańskiego Towarzystwa Przyjaciół Nauk, 2007).

${ }^{29}$ Jerzy Ziomek, Powinowactwa przez fabułę, w Jerzy Ziomek, Powinowactwa literatury. Studia i szkice, 10-11.
} 
[...] Niech się roztańczą trapezy!

Arlekin śpiący i somnambulik.

(A. Słonimski, Negatyw)

Już znika ląd, już nikną kominy i wieże, jesteśmy sami. Cisza, że słychać nieomal zimne i śliskie kamienie, które tkwią w ziemi. Idę i już nic nie wiem, w uszach mi szumi wiatr, rytm chodu mnie kołysze... Natura. Nie chcę natury, dla mnie naturą są ludzie. Miętus, wracajmy, wolę ścisk w kinematografie niż ozon pól. (W. Gombrowicz, Ferdydurke)

A tymczasem doktór (taki miejscowy Sapocolanca) amablował (do stu ciężkich choler) Perditę. To wszystko nie ma najmniejszego sensu, choć te wąsiki doktorskie, zupełnie jak u aktora filmowego...

(J. Brzękowski, 24 kochanków Perdity Loost)

Inżynier miał staromodne binokle na czarnym jedwabnym sznurku, jak by wypożyczone $\mathrm{z}$ filmu „Pancernik Potiomkin”

(B. Jasieński, Człowiek zmienia skórę)

Najczęściej opisywanym przez pisarzy elementem świata filmowego były gwiazdy ówczesnego kina. Ich obecność w świecie przedstawionym utworu literackiego podporządkowana była kilku podstawowym celom. Wielu literatów uległo modzie pisania swego rodzaju peanów na cześć aktorów i trzeba zaznaczyć, że nie byli to twórcy drugorzędni. Wśród wielu z nich można znaleźć nazwisko Juliana Tuwima, zachwycającego się gwiazdą kina amerykańskiego Lilianą Gish (List pt. Liebesleid), Konstantego Ildefonsa Gałczyńskiego, porównującego Gretę Garbo do anioła ( $L u$ dowa zabawa) czy Antoniego Słonimskiego, podkreślającego urodę Glorii Swanson (Głos Glorii Swanson).

Czuła się teraz siostrą małej Amerykanki Liliany Gish i jak ona z trudnością powstrzymywała łzy, biegnąc samotna po placach i ulicach Londynu.

(A. Słonimski, Torpeda czasu)

Wprowadzanie do literatury motywów filmowych było także okazją do autorskiego komentarza na temat aktualnych przemian kulturowych i cywilizacyjnych. Literaci włączali się w ten sposób w dyskusję między innymi o poziomie rodzimej kinematografii, przełomie dźwiękowym i jego konsekwencjach dla sztuki filmowej, wreszcie o publiczności kinowej i zagrożeniach, jakie niesie X muza.

Ewa stała naga,

Ewa stała niema,

Mówiła ręka, mówiła noga -

Było to, czego nie ma.

[...] Ewa stała biała -

Obiektyw oka skrzył pod powiek diafragmą.

Ewa zjadła owoc,

Ewa zjadła owoc słowa,

Którego jej zmysł rozkoszy pragnął.

(A. Stern, Pierwszy grzech) 


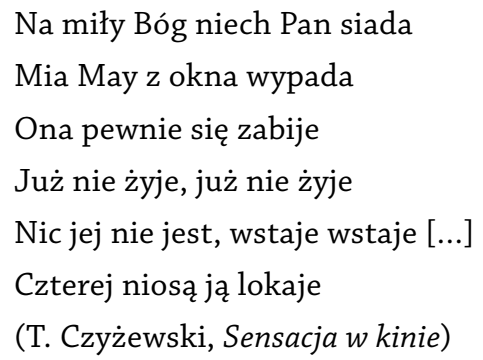

A, wpatrując się w gwiazdy całujące się z nami, W pewnym dzikim momencie po dziesiątym Clicot, Zobaczymy raptownie świat do góry nogami, Jak na filmie odwrotnym firmy Pathé \& CO.

(B. Jasieński, Rzygające posagi)

Pathé frères wszystko widzą i wszystko słyszą [...]

Więc zjednoczonych przegląd wojsk [...]

I żona Wilsona w narodowej halce

Hurra hurra

I Paderewskiego palce -

I saint-bernardski pies -

Wszystko jest.

(S. Młodożeniec, Kino)

\section{Relacje narracyjne}

Zarówno film, jak i literatura okresu międzywojennego w Polsce świadczą o wzajemnych pokrewieństwach narracyjnych, a w wielu przypadkach bezpośrednich inspiracjach. Film w literaturze objawił się jako zespół określonych form narracyjnych, technik filmowego obrazowania i prezentacji scenicznej. Jako zjawisko kulturowe początków XX wieku wywarł duży wpływ na rozumienie kategorii czasu i przestrzeni, wprowadzając skrót i swobodę wyobraźni, dramaturgiczny dynamizm oraz ruch ${ }^{30}$. Jednoznaczne wyjaśnienie zależności poszczególnych zabiegów narracyjnych przysparza jednak wiele kłopotów. Film - sztuka o zaledwie kilkudziesięcioletniej historii w międzywojniu - budował swój język eklektycznie, czerpiąc z dorobku innych sztuk, głównie literatury. Asymilował określone elementy języka, przekształcał i pokazywał w nowych barwach, stąd zabiegi dawno temu wypróbowane w literaturze często uważano za osiągnięcia $\mathrm{X}$ muzy. Tempo akcji, znamienny ruch i rytm, swoboda w operowaniu czasem i przestrzenią, swoista wizualizacji świata - szybko stały się atrybutami kina i jeśli pojawiały się w innych sztukach, brano je za filmową inspirację. Trzeba stwierdzić, że w wielu przypadkach takie postępowanie było słuszne, film przyczynił się bowiem do rozwoju samoświadomości literatury, uzmysławiając jej twórcom szerokie możliwości artystyczne, jakie w niej tkwiąą . Nie można też pominąć

\footnotetext{
${ }^{30}$ Zwraca na to uwagę np. Artur Hutnikiewicz, Od czystej formy do literatury faktu. Główne teorie i programy literackie XX stulecia (Warszawa: Państwowe Wydawnictwo Wiedza Powszechna, 1974), 51.

${ }^{31}$ Do podobnych wniosków dochodzi Alina Madej, „Między filmem a literaturą. Szkice o powieści filmowej”, w Film polski wobec innych sztuk, red. Alicja Helman i Alina Madej (Katowice: Uniwersytet Śląski, 1979), 106-108.
} 
przykładów świadczących o tym, że obie sztuki rozwijały się niejako obok siebie (utwory Jamesa Joyce'a czy Dos Passosa). Tak czy inaczej, inspiracje istniały. Przyznają się do nich wprost chociażby twórcy z kręgu Awangardy Krakowskiej czy futuryzmu; określone sygnały można również odnaleźć w poszczególnych utworach, w których autorzy umieszczali podtytuły nawiązujące do kina bądź wykorzystywali motywy i schematy fabularne, sugerując tym samym filmową inspirację. Warto zaznaczyć, że już w dwudziestoleciu, może nawet bardziej niż współcześnie, owe nawiązania dostrzegali teoretycy i krytycy literatury, przyznając im dużą rolę w kształtowaniu nowego języka poetyckiego, języka na miarę masowej publiczności i nowoczesnej kultury ${ }^{32}$.

Relacje narracyjne obu sztuk można podzielić na trzy grupy: czasowe, przestrzenne i czasoprzestrzenne, wskazując tym samym kierunki i sposoby przeobrażeń literatury pod wpływem filmu.

W wielu utworach na plan pierwszy wysuwała się swoboda w operowaniu czasem, który dowolnie skracano i rozbijano. Do sztandarowych przykładów należą utwory: Jana Brzękowskiego, Jalu Kurka, Adama Ważyka, Jerzego Andrzejewskiego, Michała Choromańskiego czy Tadeusza Peipera. We wszystkich uwidacznia się filmowa inspiracja, sygnalizowana wprost w podtytułach (Bankructwo profesora Muellera. Powieść sensacyjno-filmowa), poprzez elementy fabuły odnoszące się do kina (Andrzej Panik morderca Amundsena, Triumwirat, Psychoanalityk w podróży), wyraźne analogie struktur literackich i filmowych (Zazdrość i medycyna, Skandal w Wesołych Bagniskach) lub biografię twórcy i jego związki ze sztuką ruchomych obrazów ${ }^{33}$.

Utwory prozatorskie charakteryzują się swoistym rozbiciem czasowym opisywanych wątków, nie wynikają jedna z drugich, ale łączone są na zasadzie skojarzeń bądź na tle organizującego całość motywu filmowego. Tak jest w przypadku powieści Jalu Kurka Andrzej Panik morderca Amundsena, gdzie losy tytułowego bohater zależą od obejrzanego w kinie filmu oraz przyjaźni z osobą będącą porte-parole autora pisującego recenzje filmowe. Motyw ten zostaje zamieniony na ideę katastrofizmu w innej powieści Kurka S.O.S., w której poszczególne wątki połączone są jedynie osobami bohaterów i to nie we wszystkich miejscach, a w tok narracji autor wprowadza osobne epizody, np. aktorki Liny Gorzelskiej i Chaplina. Budowana w ten sposób kompozycja dzieła ma mozaikową konstrukcję, z podanym co prawda czasem akcji, ale niejasną temporalnie relacją między zdarzeniami ${ }^{34}$. U innych autorów ujęcia czasu wykazują jeszcze większą złożoność. Autor Psychoanalityka w podróży w dowolny sposób organizuje poszczególne wątki fabularne, stosując zwolnienia i przyspieszenia akcji oraz skojarzeniowe połączenia obrazów. Nawiązuje też do poetyki kina niemego w jego wersji sensacyjnej, gdzie dominują szybkie zwroty akcji, przyspieszenia zdarzeń, równoczesność ich przedstawiania oraz częste elipsy, oparte na ciągach obrazowych asocjacji.

Najciekawsze jednak ujęcia czasu zawarł w swoich utworach prozatorskich Michał Choromański. Swoistą grę z czasem, opartą na elipsach, zwrotach, przeskokach i równoczesności temporalnej w prezentacji zdarzeń, przeprowadził w swojej najbardziej znanej powieści Zazdrość

\footnotetext{
${ }^{32} Z$ ob. np. Karol Irzykowski, „Futuryzm a szachy”, Ponowa nr 1 (1921).

${ }^{33}$ Chodzi tu przede wszystkim o artykuły krytyczne Tadeusza Peipera, Jana Brzękowskiego, Jalu Kurka oraz działalność scenariopisarską Jerzego Andrzejewskiego.

${ }^{34} \mathrm{O}$ wpływie filmu na konstrukcję czasu w utworach Jalu Kurka pisze Janusz Kucharczyk, „Pierwiastki filmowe w twórczości literackiej Tadeusza Peipera i Jalu Kurka”, Kwartalnik Filmowy nr 1 (1965), 49-52.
} 
i medycyna. Podobnie rzecz miała się z jego utworem Skandal $w$ Wesolych Bagniskach. Pisarz skomponował dzieło na zasadzie ciągle powracającej retrospekcji tragicznych wydarzeń sprzed pięciu lat, wykorzystując jednocześnie techniki symultaniczne i cały wachlarz pomysłów związanych z zastosowaniem nagłych skoków czasowych, to w przeszłość, to w przyszłość.

Córka była w białej sukni z falbankami, jakie noszą małe dziewczynki, we włosach za prawym uchem miała wetknięty biały kwiat - aster.

Pęki białych astrów stały w pokoju Wawickiego. W szyby walił deszcz. Wawicki mył się w tubie, gdy do drzwi zapukał pan Apolinary.

(M. Choromański, Skandal w Wesołych Bagniskach)

Natomiast relacje przestrzenne i czasoprzestrzenne literatury i filmu dotyczyły głównie rozluźnienia rygorów narracyjnych, związanych z modelem powieści pozytywistycznej, z linearnym tokiem opowiadania i chronologią przedstawiania zdarzeń. Przeskokom i elipsom czasowym odpowiadały szybkie zmiany miejsc akcji, często ontologicznie spokrewnione ze sztuką ruchomych obrazów. Film zrewolucjonizował rozumienie pojęcia przestrzeni. W miejsce określeń: statyczna, niezmienna, jednorodna i jednoczesna pojawiły się przymiotniki: dynamiczna, płynna, bezgraniczna ${ }^{35}$. Film - zdaniem Aliny Madej - uwolnił literaturę od opisowości, nadał jej rytm, dynamikę i ruch ${ }^{36}$. W praktyce twórczej objawiało się to przede wszystkim poprzez dynamiczną zmienność obrazów i zmiany miejsc akcji bez wcześniejszej zapowiedzi, zgodnie z zasadami filmowego montażu opartego na systemie luźnych asocjacji. Wykorzystywano ponadto, zarówno $\mathrm{w}$ prozie, jak i w poezji, szeroko rozumianą wizualizację opisu, przedstawianie świata okiem kamery, stosowanie w opisie przestrzeni gradacji planów filmowych i ruchów kamery oraz stosowanie technik symultanizmu i montażu filmowego. Oto kilka znamiennych przykładów:

- gradacja planów filmowych:

[...] pocałunki z Florydy

Angielskie imiona

Pod gwiaździstą banderą

Murzyn w banjo bije

Tańczymy czy pan chwycił mnie nagle w ramiona

Tańczymy

Czy rzuciłam się panu na szyję

(M. Pawlikowska-Jasnorzewska, Fokstrot)

- $\quad$ sposoby filmowego obrazowania:

Młoda kobieta coś szyje.

W milczeniu szyje coś białego z koronkami.

Napis:

Wiesz, myślałam, że to będzie dla naszego maleńkiego.

\footnotetext{
${ }^{35}$ Hutnikiewicz, Od czystej formy do literatury faktu. Gtówne teorie i programy literackie XX stulecia, 51.

${ }^{36}$ Madej, „Między filmem a literaturą. Szkice o powieści filmowej”, 108.
} 
Dwie krople duże,

Najświętsze,

Płyną rowkami twarzy,

Wisną na szyi.

Dym z fajki,

Cisza trwożna.

(W. Wandurski, Kino - Dramat)

- techniki zaczerpnięte z poetyki scenariusza filmowego:

Wieczór,

Radosny pielgrzym, przyodziany lasem

Stoi przed wsią. Okopał się. Czeka. [...]

Dzień,

Pobity, rumieni się, słania, chce uciec. Ucieka.

Czerwony wstyd, łunę klęski, obwieszczając chmurom.

(J. Kurek, Bitwa dnia z nocą)

Kościół OO. Franciszkanów. Niedziela. Godzina 10 rano.

Panik stoi odświętnie ubrany, oparty o konfesjonał po prawej stronie nawy.

(J. Kurek, Andrzej Panik morderca Amundsena)

Noc zimna.

Zła.

Przejmująca. Czerniawa. Chłodnista.

Nie widać ani źdźbła,

Deszcz leje jak z cebra,

$\mathrm{Na}$ rogu policjant statysta...

(B. Jasieński, Miasto)

- techniki montażu filmowego:

Ranki wchodzą w południa, jak ludzie wchodzą w bramy

Wejdź w dzień, wciśnij się w kościół cierpiący,

Jak dłoń wciska się w dłoń, kiedy się żegnamy.

(J. Kurek, Oda do słońca)

- symultanizm:

„A tymczasem...” - jak to się mówi w filmach.

A tymczasem i kilka metrów na południowy zachód, w dzielnicy Wilmersdorf, w dużym murowanym domu (druga brama, wejście z podwórza), w jednym z mieszkań na trzecim piętrze, na rozłożonym na podłodze sienniku siedzi mężczyzna (ten sam, którego Relich w duchu przeklina) i spokojnie zdejmuje buty.

(B. Jasieński, Zmowa obojętnych) 
Opisując relacje narracyjne literatury i filmu polskiego międzywojnia, nie sposób oprzeć się wrażeniu, że był to związek niezwykle złożony i obfitujący w ciekawe przedsięwzięcia artystyczne. Temporalne zabiegi narracyjne dotyczyły szeroko pojętej swobody w operowaniu czasem. Ujęcia przestrzeni literackiej projektowano środkami stricte filmowymi, mając na uwadze głównie elementy wizualizacji oraz poetykę kinowego obrazu: ruchy kamery i plany filmowe. Czasoprzestrzenne aspekty narracji wzbogacano z kolei technikami filmowego montażu i poetyki scenariusza oraz narracyjnym symultanizmem. Tego rodzaju powinowactwa z filmem miały być dla literatury sposobem jej uatrakcyjnienia dla masowego odbiorcy, formą zburzenia tradycyjnych, archaicznych schematów narracyjnych, a także autorskim wyrazem nowatorskiego programu poetyckiego.

\section{Relacje genologiczne}

Bodźcem formotwórczym na płaszczyźnie genologii mogą być zjawiska natury: społecznej (oczekiwania odbiorców), cywilizacyjnej (postęp techniczny, nowe media) i estetycznej (powinowactwa sztuk). Pojawienie się nowej sztuki, jaką był film, i jego szerokie oddziaływanie, także w sferze genologii literackiej, dokonywało się we wszystkich powyższych aspektach. Jako nowe medium i symbol nowoczesności oraz dziedzina sztuki o największym wydźwięku społecznym X muza stała się jednym z najistotniejszych źródeł inspiracji genologicznych w polskiej literaturze międzywojnia. Zdaniem Grażyny Szymczyk-Kluszczyńskiej kino wystąpiło jako katalizator przemian w obrębie form literackich ${ }^{37}$, przyczyniając się do powstania nowych gatunków, ale również do zrewolucjonizowania myślenia o genologii w ogóle, postulując niejednorodność i synkretyzm gatunkowy.

Siłą napędową każdej epoki są ruchy awangardowe, które decydują o jej swoistości i odmienności, zarówno tematycznej, narracyjnej, jak i gatunkowej. Programowy antytradycjonalizm i nowatorstwo zmuszały do poszukiwania nowych form wyrazu. Jedną z potencjalnych możliwości okazały się nowe media, w tym film, który ze swoistą dla siebie poetyką zrytmizowanych obrazów dynamizował proces przekształceń literackich sposobów narracji. Słowo zaczęło funkcjonować w nowych warunkach kulturowych, w kontekście poszerzającej grono swoich odbiorców publicystyki, na tle rozwijającej się literatury obiegów popularnych - wszechstronnie i nowocześnie wykorzystywane przez kino i radio.

Fakt ten uzmysłowił literatom jego szerokie możliwości i potencjalną siłę oddziaływania, uzależnioną od związków z innymi sztukami, przede wszystkim z filmem. Widząc wspólne pole porozumienia $\mathrm{z}$ widzem-czytelnikiem oraz perspektywę oryginalności i nowatorstwa, twórcy awangardowi coraz częściej opatrywali swoje dzieła formułami genologicznymi zapożyczonymi z kina. Powstawały więc nie tylko gatunki zakorzenione w tradycji literackiej, z charakterystycznymi określeniami typu: powieść filmowa, opowieść filmowa, nowela filmowa, romans filmowy, sztuka filmowa, ale także dzieła w całości przejmujące nazewnictwo X muzy: scenariusz, kinematograf, film awanturniczy czy najdziwniejsze kontaminacje i propozycje autorskie: kino-dramat, cienie na ekranie, elektro-kino-aero-drama, przeróbka powieści na film.

\footnotetext{
${ }^{37}$ Grażyna Szymczyk-Kluszczyńska, „Opowiadam? Opisuję? (Poeci-surrealiści wobec kina)”, w Małe formy narracyjne, red. Eugenia Łoch (Lublin: Wyd. Uniwersytetu Marii Curie-Skłodowskiej, 1991), 102.
} 
Najistotniejszą rolę w kształtowaniu nowej poetyki i genologii sztuki słowa odegrali artyści programowo odcinający się od tradycji i poszukujący nowych środków wyrazu: futuryści, reprezentanci Almanachu Nowej Sztuki i awangardziści krakowscy. Postulując dynamizowanie sztuki oraz nowatorstwo treści i formy, tworzyli dzieła rozmaicie odbijające strukturę utworu filmowego, jego fabułę i elementy narracji. Zrodziły się w ten sposób nowe gatunki literackie międzywojnia, najczęściej podejmowane przez artystów: powieść filmowa, opowieść filmowa (racontè), scenariusz, poemat filmowy, poetycki kinematograf. Eksperymenty te były udziałem takich wybitnych autorów, jak: Jan Brzękowski, Jalu Kurek, Tadeusz Peiper, Adam Ważyk, Bruno Jasieński, Stanisław Młodożeniec, Tytus Czyżewski, Anatol Stern i inni.

Największą popularność wśród autorów zdobyła powieść filmowa, sytuująca się - jak podaje Alina Madej - na wierzchołku trójkąta, który tworzą literatura popularna i film komercjalny ${ }^{38}$. Przyczyniło się to do deprecjacji powieści filmowej jako dzieła sztuki i porównywania jej do podgatunków kultury masowej. Konstytutywny dla tego gatunku był fakt, że miał on - jak klasyczny wzorzec powieściowy - obszerną formułę dłuższego utworu prozatorskiego, wzbogaconego o elementy zaczerpnięte z poetyki X muzy i szeroko pojętej kultury popularnej. Do głównych cech tego rodzaju zaliczyć możemy: wykorzystanie konwencji scenariusza filmowego, techniki montażowe, filmowe obrazowanie świata przedstawionego, oniryzm i fantasmagoria oraz motywy i aluzje fabularne z kręgu kina, a także tematy kojarzone z niskimi obiegami kultury, takie jak: erotyka, narkomania, okultyzm i kultura Wschodu. Reprezentatywnymi przykładami tego gatunku mogą być utwory Jana Brzękowskiego - Psychoanalityk w podróży oraz Jalu Kurka - Bankructwo profesora Muellera.

Wśród wielu sposobów „ufilmowienia” literatury międzywojnia najbardziej związane, oprócz scenariusza, z przemysłem kinematograficznym było racontè, czyli opowieść filmowa. To utwór epicki powstały na podstawie gotowego dzieła filmowego lub jego literackiego opracowania w formie scenariusza. Jak podaje Barbara Mruklik, bezpośrednią przyczyną ukształtowania się tego gatunku był rozwój w latach dwudziestych propagandy filmowej, kiedy to racontè traktowano jako jedną z form reklamy premierowych produkcji, stanowiącą właściwie obszerne streszczenie opatrzone licznymi fotosami ${ }^{39}$. Z formy reklamy opowieść filmowa przekształciła się w rodzaj literatury z kręgu obiegów kultury popularnej, czytanej w celu przypomnienia sobie obejrzanego wcześniej filmu i powtórnego przeżycia wrażeń z sali kinowej. Ponadto przyczyniło się do standaryzacji możliwości narracyjnych sztuki filmowej, stabilizacji znaczenia filmu w kulturze oraz edukacji widza wyrosłego w dobie słowa i druku ${ }^{40}$.

Racontè występuje w czterech wariantach w zależności od funkcji, jaką utwór ma spełniać i ambicji jego autora. Typ pierwszy jest streszczeniem z przewagą materiału fotograficznego, zbliżony do komiksu; typ drugi to przekształcony w formę narracyjną scenariusz spełniający głównie funkcje utrwalania i wzmacniania przeżycia z sali kinowej; typ trzeci odpowiada scenariuszowi właściwemu o charakterze opowieści filmowej, tzn. pisanemu na podstawie gotowego filmu, ma on przede wszystkim wartość materiału dokumentalnego; wreszcie typ czwarty to forma twórczej interpretacji tego, co prezentowało dzieło filmowe. Polskie międzywojenne realizacje gatunku wpisywały się za-

\footnotetext{
${ }^{38}$ Madej, „Między filmem a literaturą. Szkice o powieści filmowej”, 113.

${ }^{39}$ Barbara Mruklik, hasło „Racontè”, w Zagadnienia Rodzajów Literackich, z. 2 1961/1962: 207-208.

${ }^{40}$ Szymczyk-Kluszczyńska, „Opowiadam? Opisuję? (Poeci-surrealiści wobec kina)”, 103.
} 
zwyczaj w ramy wariantu drugiego i trzeciego. Bardziej od innych ambitne wydaje się jedynie dzieło Leo Belmonta Człowiek, z którego świat się śmieje (1928), w którym autor odwołał się do Cyrku Charliego Chaplina, dokonując jednak jego twórczego literackiego opracowania. Oryginalność i autorskie piętno Belmonta przejawiały się przede wszystkim w rozbudowaniu przedakcji i epilogu w celu zarysowania biografii głównego bohatera, a także w nowatorskim ujęciu czasu powieściowego, wprowadzeniu wątków metatekstowych oraz analizy psychologicznej i omówieniu zagadnień komizmu.

Na obrzeżach literackiej twórczości autorów międzywojnia znajdowały się i inne gatunki, np. poemat filmowy czy poetyckie kinematografy. Nie odegrały one jednak znaczącej roli kulturotwórczej, były raczej wyrazem ekspresji i zainteresowań indywidualnych osobowości twórczych, nawiązujących do surrealizmu (Jan Brzękowski, Adam Ważyk) przejawiających inspiracje włoskim futuryzmem (Jalu Kurek) lub realizujących się na płaszczyźnie szeroko pojętych eksperymentów gatunkowych (Stefan K. Gacki, Stanisław Grędziński). Podobnie jak w tradycji europejskiej ich utwory miały charakter otwarty i niekonwencjonalny, jako twórcza transpozycja założeń genologicznych z wyraźnym piętnem autora. Wśród stosowanych przez nich chwytów o proweniencji filmowej na uwagę zasługują: subiektywizacja punktu widzenia bohatera (w transie alkoholowym i narkotycznym lub we śnie), względność i nieokreśloność czasu i przestrzeni, budowanie rzeczywistości na zasadzie montażu skojarzeniowego, symultanizm, wykorzystanie technik filmowego obrazowania. Najbardziej udane realizacje tego wzorca gatunkowego wyszły spod pióra Jalu Kurka (Gotębie Winicji Claudel, 1924) oraz Jana Brzękowskiego (Montparnasse, 1928).

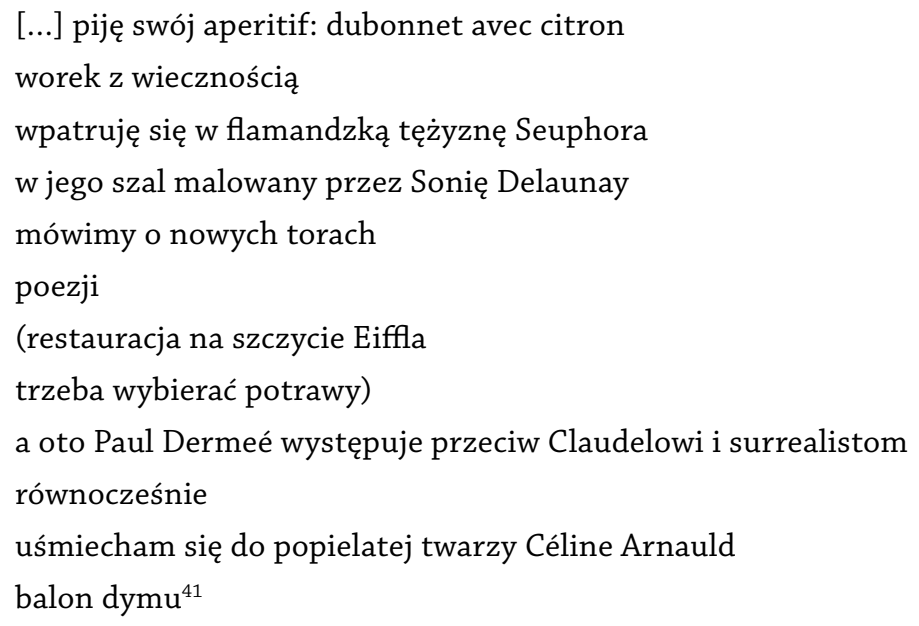

Poetyckie kinematografy zrodziły się natomiast z naturalnej potrzeby wzbogacenia słownika gatunków literackich, czemu hołdowali przede wszystkim futuryści. Jak zauważa Edward Balcerzan, wśród proponowanych przez nich nowych propozycji nazewniczych znalazły się m.in. „poezy”, ,,namopaniki”, ,futurostychy”, ,futureski”, ,futuryzje”, „syntezje” i „,kinematografy”42. W tej grupie wykształcił się szczególny typ utworów poetyckich, stanowiących literackie odtworzenie rzeczywistości ekranowej jako, dosłownie, „zapis ruchu”43. Takim słownym zapisem

\footnotetext{
${ }^{41}$ Jan Brzękowski, „Montparnasse”, w Poezje, (Warszawa: Ludowa Spółdzielnia Wydawnicza, 1973), 43.

${ }^{42}$ Edward Balcerzan, „Wstęp”, w Bruno Jasieński, Utwory poetyckie, manifesty, szkice (Kraków: Zakład Narodowy im. Ossolińskich, 1972), LXI-LXII.

${ }^{43}$ Nazwa „poetyckie kinematografy” pochodzi od podtytułu jednego z wierszy Brunona Jasieńskiego Przejechali (1920) i oznacza dosłownie „zapis ruchu”.
} 
będzie np. relacja oglądanego na ekranie filmu, jego fabuły, w całości lub w części, bądź próba oddania struktury narracyjnej utworu filmowego środkami poetyckimi albo - jako możliwość trzecia - połączenie dwóch powyższych. Były one pisane niejako post factum, po projekcji danego filmu, z wykorzystaniem sceny lub całej opowiadanej historii, albo realizując określony model fabularny bądź narracyjny gatunku filmowego czy typu kinematografii. W przypadku relacji fabularnej można mówić o tzw. opowiadaniu unaoczniającym, które - jak podaje Tadeusz Brzozowski - zasadza się na żywości i konkretyzmie przedstawiania ${ }^{44}$. Narracja prowadzona jest na ogół w czasie teraźniejszym lub, co rzadziej, w przeszłym, sygnalizując jednak pierwotność wersji ekranowej. Czystą jego postać realizują m.in. wiersze: $Z$ kinematografu (1920) Juliana Tuwima, Cinema (1927) Tytusa Czyżewskiego, Koń w kinie (1930) Konstantego Ildefonsa Gałczyńskiego oraz Film amerykański (1924) Marii Pawlikowskiej-Jasnorzewskiej. Wariant drugi poetyckich kinematografów przyjmują wiersze oddające filmową strukturę narracyjną. Przebieg fabularny schodzi na plan drugi, co oznacza, że prezentowana sytuacja liryczna mogła mieć miejsce na ekranie kina, ale najważniejsze są tu zabiegi poety, by środkami literackimi oddać poetykę X muzy. Nawiązaniem do struktury filmu kryminalnego jest np. utwór Brunona Jasieńskiego zatytułowany Morga (1921):

Przystanęło kilku ciekawych.

Patrzyli. Pytali.

Dolatywały pojedyncze słowa.

Jakaś rozmowa urywana, krótka,

Prowadzona ściszonym staccatem...

... 25 lat ... Prostytutka ...

... sublimatem ...

Podnieśli nosze. Weszli do sieni.

Deszcz padał... krople tłukły o dach...

Połączenie dwóch powyższych wariantów realizują utwory mające cechy filmowej narracji oraz założoną, możliwą lub faktyczną, relację fabuły bądź jej fragmentu z ekranu kinowego. Dla przykładu Przejechali Brunona Jasieńskiego to krótka scena filmowa niedwuznacznej rozmowy służącej i, zapewne, mężczyzny wśród ulicznego zgiełku, zarejestrowana kamerą i rytmicznie zmontowana:

Piegowata służąca w białej bluzce w groszki.

Ktoś wysmukły, z rejerem.

Przyjedziesz?... - „Nie mogę...”

Hooop!!

Samochody. Platformy. Dorożki ${ }^{45}$.

\footnotetext{
${ }^{44}$ Tadeusz Brzozowski, „Gra w psychoanalizę, czyli (de)konstrukcja podmiotu w «filmowo-fotograficznym» modelu poezji «Almanachu Nowej Sztuki»”, w Z problemów podmiotowości w literaturze polskiej XX wieku, red. Mirosław Lalak (Szczecin: Wydawnictwo Naukowe Uniwersytetu Szczecińskiego, 1993), 207.

${ }^{45}$ Edward Balcerzan zwraca uwagę na scenariuszowy charakter tego wiersza. Zob. Edward Balcerzan, „Systemy i przemiany gatunkowe w liryce lat 1918-1939", w Problemy Literatury Polskiej lat 1890-1939, seria II, red. Hanna Kirchner i Zbigniew Żabicki (Wrocław: Zakład Narodowy im. Ossolińskich, Wyd. PAN, 1974), 180-181.
} 
Podstawą przeprowadzonej refleksji była świadomość istnienia wyraźnych korespondencji, powinowactw i paraleli pomiędzy sztuką literacką a sztuką filmową. Dokonane ustalenia teoretyczne z wprowadzoną egzemplifikacją potwierdziły supozycje co do komplementarności obu sztuk, umożliwiły precyzyjną identyfikację tzw. punktów stycznych pomiędzy interesującymi typami literackich wypowiedzi oraz rozpoznanie charakteru owych interakcji. Konkludując, stwierdzić należy, że:

- związki między obiema sztukami mają dwutorowy, czyli paralelny charakter,

- ich wzajemne relacje są różnorodne i wielopłaszczyznowe,

- filmowość literatury może być rozpatrywana jako nawiązania pośrednie (wspólnota, homologia) i bezpośrednie (filmowość właściwa) do filmu,

- podczas analizy strukturalnej poszczególnych dzieł literackich należy uwzględnić również perspektywę socjokulturową,

- inspiracje literatury sztuką filmową można rozpatrywać na płaszczyźnie fabularnej, narracyjnej i genologicznej.

\section{Bibliografia}

Balcerzan, Edward. „Systemy i przemiany gatunkowe w liryce lat 1918-1939". W Problemy Literatury Polskiej lat 1890-1939. Seria II. Zredagowane przez Hanna Kirchner i Zbigniew Żabicki. Wrocław: Zakład Narodowy im. Ossolińskich, Wyd. PAN, 1974.

-——. Wstęp. W Bruno Jasieński. Utwory poetyckie, manifesty, szkice, LXI-LXII. Kraków: Zakład Narodowy im. Ossolińskich, 1972.

Bazin, André. „O film nieczysty: obrona adaptacji”. W André Bazin. Film i rzeczywistość. Przetłumaczone przez Bolesław Michałek. Warszawa: Wydawnictwa Artystyczne i Filmowe, 1963.

Białostocki, Jan. „Słowo i obraz”. W Słowo i obraz: materiały Sympozjum Komitetu Nauk o Sztuce PAN. Zredagowane przez Agnieszka Morawińska. Warszawa: Państwowe Wydawnictwo Naukowe, 1982.

Brzękowski, Jan. „Film a nowa poezja”. Wiadomości Literackie nr 28 (1933).

———. „Poezje”. Warszawa: Ludowa

Brzozowski, Tadeusz. „Gra w psychoanalizę, czyli (de)konstrukcja podmiotu w «filmowo- fotograficznym» modelu poezji «Almanachu Nowej Sztuki»”. W Z problemów podmiotowości w literaturze polskiej XX wieku. Zredagowane przez Mirosław Lalak. Szczecin: Wydawnictwo Naukowe Uniwersytetu Szczecińskiego, 1993.

Eichenbaum, Borys. „Literatura i kino”. W Borys Eichenbaum. Szkice o prozie i poezji. Przetłumaczone przez Roman Zimand. Warszawa: Państwowy Instytut Wydawniczy, 1973.

Eisenstein, Siergiej. Wybór pism. Zredagowane przez Reginę Dreyer. Przekład zbiorowy. Warszawa: Wydawnictwa Artystyczne i Filmowe, 1959.

Gombrich, Ernst H. „W poszukiwaniu historii kultury”. Przetłumaczone przez Adam Dębnicki. W Pojęcia, problemy, metody wspótczesnej nauki o sztuce. Zredagowane przez Jan Białostocki. Warszawa: Państwowe Wydawnictwo Naukowe, 1976.

Has-Tokarz, Anita. „Między słowem a obrazem: afiliacje literatury i filmu (perspektywa komparatystyczna)". Folia Bibliologica nr XLVIII/XLIX (2006-2007): 99-100.

Hauser, Arnold. Społeczna historia sztuki i literatury, t. 1-2. Przetłumaczone przez 
Janina Ruszczycówna. Warszawa: Państwowy Instytut Wydawniczy, 1974.

Hopfinger, Maryla. Doświadczenia audiowizualne: o mediach $w$ kulturze współczesnej. Warszawa: Sic!, 2003.

\footnotetext{
. Kultura audiowizualna u progu XXI wieku. Warszawa: Wydawnictwo IBL, 1997.

. Kultura wspótczesna - audiowizualność. Warszawa: Państwowy Instytut Wydawniczy, 1985.
}
_——. „Literatura w kulturze audiowizualnej”. Pamiętnik Literacki z. 1 (1992).
———. „Między reprodukcją a symulacją rzeczywistości. Problemy audiowizualności i percepcji”. W Od fotografii do rzeczywistości wirtualnej. Zredagowane przez Maryla Hopfinger. Warszawa: Wydawnictwo IBL, 1997.
Hutnikiewicz, Artur. Od czystej formy do literatury faktu. Główne teorie i programy literackie XX stulecia. Warszawa: Państwowe Wydawnictwo Wiedza Powszechna, 1974.

Intersemiotyczność. Literatura wobec innych sztuk (i odwrotnie). Zredagowane przez Stanisław Balbus, Andrzej Hejmej i Jakub Niedźwiedź. Kraków: Universitas, 2004.

Irzykowski, Karol. Dziesiąta Muza. Zagadnienia estetyczne kina. Warszawa: Wydawnictwa Artystyczne i Filmowe, 1977.

\section{_—_ . „Futuryzm a szachy”, Ponowa nr 1 (1921).}

Jazownik, Maria, Jazownik, Leszek. „Formy obecności filmu w literaturze fikcjonalnej”. W Ze srebrnego ekranu na papier... Ślady sztuki filmowej $w$ literaturze. Zredagowane przez Dorota Kulczyckiej. Zielona Góra: Oficyna Wydawnicza Uniwersytetu Zielonogórskiego, 2019.

Kucharczyk, Janusz. „Pierwiastki filmowe w twórczości literackiej Tadeusza Peipera i Jalu Kurka". Kwartalnik Filmowy nr 1 (1965).

Kurczab, Henryk. Pogranicza sztuki konteksty literatury pięknej. Rzeszów: Wyd. Wyższej Szkoły Pedagogicznej, 2001.

Kuźnicka, Joanna. „Ut pictura poesis”. Prace Naukowe. Pedagogika nr 8-9-10 (1999-20002001).
Madej, Alina. „Między filmem a literaturą. Szkice o powieści filmowej”. W Film polski wobec innych sztuk. Zredagowane przez Alicja Helman i Alina Madej. Katowice: Uniwersytet Śląski, 1979.

Mruklik, Barbara. Hasło „Racontè”. W Zagadnienia Rodzajów Literackich, z. 2 1961/1962.

Otto, Wojciech. Literatura i film w kulturze polskiej dwudziestolecia międzywojennego. Poznań: Wydawnictwo Poznańskiego Towarzystwa Przyjaciół Nauk, 2007.

Pelc, Janusz. Słowo i obraz: na pograniczu literatury i sztuk plastycznych. Kraków: Towarzystwo Autorów i Wydawców Prac Naukowych Universitas, 2002.

Plisiecki, Janusz. „Przemiany w kulturze współczesnej”. W Janusz Plisiecki. Film i sztuki tradycyjne. Lublin: Wydawnictwo Uniwersytetu Marii Curie-Skłodowskiej, 1999.

Pogranicza i korespondencje sztuk. Zredagowane przez Teresa Cieślikowska i Janusz Sławiński. Wrocław: Zakład Narodowy im. Ossolińskich, 1980.

Pytaszowie, Ewa i Marek. „Poetycka podróż w świat kinematografu, czyli kino w poezji polskiej lat 1914-1925”. W Szkice z teorii filmu. Zredagowane przez Alicji Helman i Tadeusza Miczki. Katowice: Uniwersytet Śląski w Katowicach, 1978.

Stachowicz, Jerzy. Komputery, powieści i kino nieme. Procesy remediacji w perspektywie historycznej. Warszawa: Wydawnictwa Uniwersytetu Warszawskiego, 2018.

Stern, Anatol. „U źródeł nowej estetyki”. W Anatol Stern. Poezja zbuntowana. Warszawa: Państwowy Instytut Wydawniczy, 1964.

Szymczyk-Kluszczyńska, Grażyna. „Opowiadam? Opisuję? (Poeci-surrealiści wobec kina)”. W Małe formy narracyjne. Zredagowane przez Eugenia Łoch. Lublin: Wyd. Uniwersytetu Marii Curie-Skłodowskiej, 1991.

Ślósarz, Anna. „Dwa bieguny filmowych afordancji w literaturze XXI wieku”. W Ze srebrnego ekranu na papier... Ślady sztuki filmowej $w$ literaturze. Zredagowane przez Dorota Kulczycka. Zielona Góra: Oficyna Wydawnicza Uniwersytetu Zielonogórskiego, 2019. 
Walzel, Oskar. „O wzajemnym oświetlaniu się sztuk”. Przetłumaczone przez Elżbieta Feliksiak. Przegląd Humanistyczny nr 4 (1966).

Wellek, René. „Literatura wobec innych sztuk". W René Wellek, Austin Warren. Teoria literatury. Przetłumaczone przez Maciej Żurowski. Warszawa: Państwowe Wydawnictwo Naukowe, 1970.

Wysłouch, Seweryna. Literatura a sztuki wizualne. Warszawa: Wydawnictwo Naukowe PWN, 1991.

———. „O «wzajemnym oświetlaniu się sztuk» raz jeszcze”, Polonistyka nr 8 (2002).

Zahorska, Stefania. „Co powieść zawdzięcza filmowi?". Kurier Literacko-Naukowy nr 29 (1934).

Zeic-Piskorska, Maria. Próba typologii przejawów tzw. filmowości w utworach literackich. „Acta Universitatis Nicolai Copernici”, Filologia Polska XIX, z. 119, Toruń 1981.

Ziomek, Jerzy. Powinowactwa literatury. Studia i szkice. Warszawa: Państwowe Wydawnictwo Naukowe, 1980.

Żółkiewski, Stefan. Kultura. Socjologia. Semiotyka literacka. Studia. Warszawa: Państwowy Instytut Wydawniczy, 1979. 


\title{
SEOWA KLUCZOWE:
}

\section{literatura}

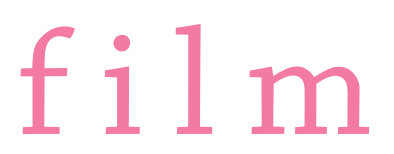

D W U D Z I E S T O L E C I E M Ę D Z Y W J E N N E

\begin{abstract}
AbstrakT:
Podstawą przeprowadzonej refleksji jest świadomość istnienia wyraźnych korespondencji, powinowactw i paraleli pomiędzy literaturą a filmem. Dokonane ustalenia teoretyczne z wprowadzoną egzemplifikacją umożliwiają precyzyjną identyfikację tzw. punktów stycznych pomiędzy sztuką słowa a sztuką ekranu oraz rozpoznanie charakteru owych interakcji. Związki między filmem a literaturą mają dwutorowy, czyli paralelny charakter, a ich wzajemne relacje są różnorodne i wielopłaszczyznowe. Filmowość literatury może być rozpatrywana jako nawiązania pośrednie (wspólnota i homologia struktur) i bezpośrednie (filmowość właściwa) do filmu. Podczas analizy strukturalnej poszczególnych dzieł literackich należy uwzględnić również perspektywę socjokulturową, zawężoną do określonej formacji społeczno-kulturowej, w tym przypadku ograniczonej cezurami roku 1918 i 1939. Inspiracje literatury sztuką filmową można rozpatrywać na płaszczyźnie fabularnej, narracyjnej i genologicznej.
\end{abstract}


teorie | Wojciech Otto, O filmowości literatury: korespondencje, powinowactwa, paralele

\section{Nota O AUTORze:}

Wojciech Otto - profesor Uniwersytetu im. Adama Mickiewicza w Poznaniu. Autor książek: Literatura i film w kulturze polskiej dwudziestolecia międzywojennego, Obrazy niepetnosprawności w polskim filmie oraz monografii Zdzisław Maklakiewicz, a także artykułów w czasopismach i tomach zbiorowych z zakresu historii filmu, scenariopisarstwa, korespondencji sztuk i kultury medialnej. Współautor ogólnopolskiego projektu edukacyjnego „Filmoteka Szkolna”, juror na festiwalach filmowych i scenariuszowych, opiekun młodzieżowego jury na Festiwalu Debiutów Filmowych „Młodzi i Film” w Koszalinie oraz na Europejskim Festiwalu Filmowym „Integracja Ty i Ja” w Koszalinie. 